\title{
Isolation and characterization of new Methanosarcina mazei strains KOR-3, $-4,-5$, and -6 from an anaerobic digester using pig slurry
}

\author{
Urantulkhuur Battumur ${ }^{1,2}$, Youngman Yoon ${ }^{3}$, Gui Sek Bae ${ }^{4}$, and Chang-Hyun Kim ${ }^{3,5, *}$
}

* Corresponding Author: Chang-Hyun Kim Tel: +82-31-670-5095; Fax: +82-31-670-5099;

E-mail: kimch@hknu.ac.kr

'Graduate School of Future Convergence, Hankyong National University, Anseong 17579, Korea

${ }^{2}$ School of Animal Science and Biotechnology,

Mongolian University of Life Sciences, Ulaanbaatar

17024, Mongolia

3 Biogas Research Center, Hankyong National University, Anseong 17579, Korea

${ }^{4}$ Department of Animal Science and Technology, Chung-Ang University, Anseong 17546, Korea

${ }^{5}$ Department of Animal Life and Environment Science,

Hankyong National University, Anseong 17579, Korea

Submitted Oct 26, 2016; Revised Nov 28, 2016; Accepted Dec 29, 2016
Objective: An experiment was conducted to isolate and identify new methanogens in Korea from an anaerobic digester that uses pig slurry.

Methods: An anaerobic digestate sample was collected from an anaerobic digester using pig slurry. Pre-reduced media were used for the growth and isolation of methanogens. Growth temperature range, $\mathrm{pH}$ range, $\mathrm{NaCl}$ concentration range, substrate utilization, and antibiotic tolerance were investigated to determine the physiological characteristics of isolated methanogens. The isolates were also examined microscopically for their morphology and Gram-stained. Polymerase chain reaction of $16 \mathrm{~S} r R N A$ and $m c r A$ gene-based amplicons was used for identification purpose. Results: Four strains, designated KOR-3, $-4,-5$, and -6 , were isolated and were non-motile, irregular coccoid, and 0.5 to $1.5 \mu \mathrm{m}$ in diameter. Moreover, the cell walls of isolated strains were Gram-negative. KOR-3 and KOR-4 strains used acetate for methane production but did not use $\mathrm{H}_{2}+\mathrm{CO}_{2}$, formate, or methanol as a growth substrate KOR-5 and KOR- 6 strains utilized acetate, methanol, and trimethylamine for methanogenesis but did not use $\mathrm{H}_{2}+\mathrm{CO}_{2}$ or formate as a growth substrate. The optimum temperature and $\mathrm{pH}$ for growth of four strains were $39^{\circ} \mathrm{C}$ and 6.8 to 7.2 , respectively. The optimum concentration of $\mathrm{NaCl}$ for growth of $\mathrm{KOR}-3, \mathrm{KOR}-5$, and KOR-6 were $1.0 \%(\mathrm{w} / \mathrm{v})$. The optimum $\mathrm{NaCl}$ concentration for KOR- 4 was $0.5 \%(\mathrm{w} / \mathrm{v})$. All of the strains tolerated ampicillin, penicillin G, kanamycin, streptomycin, and tetracycline; however, chloramphenicol inhibited cell growth. Phylogenetic analysis of 16S rRNA and $m c r A$ genes demonstrated that strains KOR-3, $-4,-5$, and -6 are related to Methanosarcina mazei (M. mazei, 99\% sequence similarity).

Conclusion: On the basis of physiological and phylogenetic characteristics, strains KOR-3, -4 , -5 , and -6 are proposed to be new strains within the genus Methanosarcina, named M. mazei KOR-3, $-4,-5$, and -6 .

Keywords: Methanogen; Anaerobic Digester; 16S rRNA; mcrA; Methanosarcina mazei

\section{INTRODUCTION}

The natural degradation of livestock wastes during storage emits $\mathrm{CH}_{4}$ to the atmosphere owing to anaerobic decomposition of organic matter. These emissions mainly originate from swine (38\%), dairy (21\%), and poultry (9\%) livestock wastes [1]. However, the amount of methane emitted varies greatly based on the type of animal, its diet, and relevant manure management practices [2]. To date, a number of methanogens, placed in a wide range of taxonomic groups within the phylum Euryarchaeota, have been isolated from various methanogenic treatment processes and characterized as novel species that belong to genera such as Methanobacterium, Methanosarcina, Methanoculleus, and Methanosaeta [3]. Some mesophilic Methanosarcina species reduce $\mathrm{CO}_{2}$ with $\mathrm{H}_{2}$; however, formate, secondary alcohols, and ethanol are not used as electron donors. Methanosarcina is a methanogenic bacteria genus that has been known for a long time. According to Bergey's manual of systematic bacteriology (second edition), this genus currently comprises ten 
species: Methanosarcina barkeri (M. barkeri), Methanosarcina acetivorans (M. acetivorans), Methanosarcina baltica, Methanosarcina lacustris (M. lacustris), Methanosarcina mazei (M. mazei), Methanosarcina methanica, Methanosarcina semesiae, Methanosarcina siciliae, Methanosarcina thermophile, and Methanosarcina vacuolata (M. vacuolata) [4]. M. mazei and M. barkeri are the most representative mesophilic species of the genus [5]. In addition, molecular surveys targeting the $16 \mathrm{~S}$ rRNA gene or $\mathrm{mcr} A$ gene, which encodes the alpha subunit of methyl coenzyme $\mathrm{M}$ reductase (MCR), have revealed that numerous unidentified methanogens may exist in such ecosystems as anaerobic digester [6].

Agricultural, municipal and industrial wastes, sewage sludge, and manure from pigs, cattle, and chickens can produce methane via biological anaerobic processes. In Korea, anaerobic digestion technology has been of great interest after a ban on ocean dumping of animal manure, sewage sludge, and food waste [7]. There are about 49 biogas plants in South Korea; however, since existing biogas plants are not efficiently they produce less methane than expected, have high operational costs and are generally considered to be economically and technologically unsuccessful [7]. Therefore, there is an emerging need to improve anaerobic digestion technologies and advance our understanding of the microbiology involved in anaerobic digesters that use pig slurry.

Given that methanogens are difficult to study through culturebased methods, many researchers have instead used cultureindependent techniques, such as real-time polymerase chain reaction (qPCR), denaturing gradient gel electrophoresis, and sequencing approaches, which have proven to be valuable tools for studying the biodiversity of complex microbial communities, such as those in anaerobic digesters [8]. Here, we have isolated four M. mazei strains from an anaerobic digester that uses pig slurry. This is the second time that we isolated new methanogens after isolation of Methanobacterium formicium KOR-1 [8]. This study describes the characteristics of four strains isolated from an anaerobic digester that uses pig slurry.

\section{MATERIALS AND METHODS}

\section{Source of inoculum}

An anaerobic digestate sample (2 L) was collected in May 2011 from an anaerobic digester in the Biogas Research Center, Hankyong National University, Republic of Korea, which was built in early 2008 and was kept running for about 4 years [8]. Pig slurry from a pig farm was the main substrate used by the anaerobic digester. The anaerobic digestate from the digester was characterized, showing a total volatile fatty acid concentration of 4,500 ppm, $\mathrm{pH}$ of 8.2, and chemical oxygen demand of 70,000 ppm. The anaerobic digestate was inoculated into medium to isolate methanogens.

\section{Medium}

Methanogens are highly sensitive to oxygen and need strict anoxic conditions; therefore, pre-reduced media are critical for their growth and isolation. The methods used for the preparation of media and substrate solutions and culture techniques were those of Hungate [9], as modified by Balch et al [10]. For enrichment culture and isolation, basal medium was prepared with the modification from Sowers and Schreier [11] and contained the following compounds (per liter distilled water): $\mathrm{KCl}, 0.335 \mathrm{~g} ; \mathrm{MgCl}_{2} \cdot 6 \mathrm{H}_{2} \mathrm{O}$, $2.75 \mathrm{~g} ; \mathrm{MgSO}_{4} \cdot 7 \mathrm{H}_{2} \mathrm{O}, 3.450 \mathrm{~g} ; \mathrm{NH}_{4} \mathrm{Cl}, 0.25 \mathrm{~g} ; \mathrm{CaCl}_{2} \cdot 2 \mathrm{H}_{2} \mathrm{O}, 0.14 \mathrm{~g}$; $\mathrm{K}_{2} \mathrm{HPO}_{4}, 0.14 \mathrm{~g} ; \mathrm{NaCl}, 18.0 \mathrm{~g}$; trace element solution, $10.0 \mathrm{~mL}$; vitamin solution, $10.0 \mathrm{~mL} ; \mathrm{Fe}\left(\mathrm{NH}_{4}\right)_{2}\left(\mathrm{SO}_{4}\right)_{2} \cdot 7 \mathrm{H}_{2} \mathrm{O}, 0.002 \mathrm{~g} ; \mathrm{NaHCO}_{3}$, 5.0 g; methanol, $5.0 \mathrm{~mL}$; sodium acetate, 2.5 g; yeast extract, 2.0 $\mathrm{g}$; trypticase peptone, $2.0 \mathrm{~g}$; resazurin, $0.001 \mathrm{~g}$; cysteine hydrochloride, $0.5 \mathrm{~g}$; and $\mathrm{Na}_{2} \mathrm{~S} \cdot 9 \mathrm{H}_{2} \mathrm{O}, 0.5 \mathrm{~g}$. The trace element solution was made up of the following (in one liter of distilled water): $\mathrm{ZnSO}_{4} \cdot 7 \mathrm{H}_{2} \mathrm{O}, 0.1 \mathrm{~g} ; \mathrm{MnCl}_{2} \cdot 4 \mathrm{H}_{2} \mathrm{O}, 0.03 \mathrm{~g} ; \mathrm{H}_{3} \mathrm{BO}_{3}, 0.3 \mathrm{~g} ; \mathrm{CoCl}_{2} \cdot 6 \mathrm{H}_{2} \mathrm{O}$, $0.2 \mathrm{~g} ; \mathrm{CuCl}_{2} \cdot 2 \mathrm{H}_{2} \mathrm{O}, 0.01 \mathrm{~g} ; \mathrm{NiCl}_{2} \cdot 6 \mathrm{H}_{2} \mathrm{O}, 0.02 \mathrm{~g}$; and $\mathrm{Na}_{2} \mathrm{MoO}_{4} \cdot 2 \mathrm{H}_{2} \mathrm{O}$, $0.03 \mathrm{~g}$. First, the minerals were dissolved with $500 \mathrm{~mL}$ distilled water and adjusted to $\mathrm{pH} 3.4$ and then the solution was made up to a volume of $1,000 \mathrm{~mL}$. The vitamin solution was made up of the following (in one liter of distilled water): biotin, $0.02 \mathrm{~g}$; folic acid, $0.02 \mathrm{~g}$; pyridoxine hydrochloride, $0.1 \mathrm{~g}$; thiamine hydrochloride, $0.05 \mathrm{~g}$; riboflavin, $0.05 \mathrm{~g}$; nicotinic acid, $0.05 \mathrm{~g}$; calcium pantothenate, $0.05 \mathrm{~g}$; vitamin $\mathrm{B}_{12}, 0.01 \mathrm{~g}$; $p$-aminobenzoic acid, $0.05 \mathrm{~g}$; and thioctic acid, $0.05 \mathrm{~g}$. Clarified sludge fluid was prepared following the method from Battumur et al [8]. The sludge fluid $(5 \%, v / v)$ was used to supply unknown growth factors. The medium was prepared under a $\mathrm{H}_{2} / \mathrm{CO}_{2}(80: 20$, v/v) gas phase at $173 \mathrm{kPa}(25 \mathrm{psi})$. The medium was adjusted to $\mathrm{pH} 6.8$ to 7.0 and sterilized by autoclaving at $121^{\circ} \mathrm{C}$ for $30 \mathrm{~min}$.

\section{Enrichment and isolation}

Enrichments were achieved in the basal medium, which was adjusted to $\mathrm{pH} 7.0$ under $\mathrm{H}_{2} / \mathrm{CO}_{2}(80: 20$, v/v) gas phase. Vials containing medium $(45 \mathrm{~mL})$ were inoculated with a $5-\mathrm{mL}$ inoculum. The growth of non-methanogenic organisms was inhibited by adding streptomycin sulfate $\left(7 \times 10^{4} \mathrm{IU} / \mathrm{L}\right)$ and benzyl penicillin $\left(2 \times 10^{10}\right.$ $\mathrm{IU} / \mathrm{L})$ to the medium. The inoculated medium was cultured in the dark at $38^{\circ} \mathrm{C}$ for two weeks. After detection of high amounts of methane in the culture, $5 \mathrm{~mL}$ of the culture was anaerobically transferred into new, sterile basal medium. Roll tubes containing the basal medium with $1.8 \%$ agar were prepared followed by four successive transfers. Well-isolated colonies were withdrawn with Pasteur pipettes and transferred to culture tubes containing the basal medium under anaerobic condition. The culture tubes were closed with butyl-rubber stoppers and repressurized with sterile filtered $\mathrm{H}_{2} / \mathrm{CO}_{2}(80: 20$, v/v) at $173 \mathrm{kPa}(25 \mathrm{psi})$. The organism was re-isolated with agar medium from the liquid cultures. It was inoculated on bacterial growth medium to check the purity of methanogen cultures. The bacterial growth medium contained peptone $(2.5 \mathrm{~g} / \mathrm{L})$, yeast extract $(2.5 \mathrm{~g} / \mathrm{L})$, D-glucose $(0.5 \mathrm{~g} / \mathrm{L})$, Dcellobiose $(0.5 \mathrm{~g} / \mathrm{L})$, and D-xylose $(0.5 \mathrm{~g} / \mathrm{L})$ in the basal medium. 
For further purification of the isolated strains KOR-3, -4, -5, and -6 , an antibiotic mixture was prepared that contained four antibiotics (benzyl penicillin, $0.5 \mathrm{mg} / \mathrm{mL}$; streptomycin sulfate, 0.5 $\mathrm{mg} / \mathrm{mL}$; vancomycin- $\mathrm{HCl}, 0.2 \mathrm{mg} / \mathrm{mL}$; and ampicillin, $0.2 \mathrm{mg} / \mathrm{mL}$ ). After purification, the isolates were incubated in the basal media without antibiotics. We isolated ten methanogens from the isolation process. Strains KOR-3, $-4,-5$, and -6 were microscopically distinct, with a coccal shape compared to the rod shape of other isolated methanogens.

\section{Physiological studies}

Growth temperature range, $\mathrm{pH}$ range, $\mathrm{NaCl}$ concentration range, substrate utilization, and antibiotic tolerance were investigated to determine the physiological characteristics of strains KOR-3, $-4,-5$, and -6 . Growth was verified by observing optical density $(\mathrm{OD})$ at $660 \mathrm{~nm}\left(\mathrm{OD}_{660}\right)$ with a spectrophotometer (V-530, Jasco, Tokyo, Japan) and by measuring the concentration of methane in the gas phase using a gas chromatograph (GC-2010A, Shimadzu, Kyoto, Japan). All experiments for physiological studies were repeated twice.

Basal medium, with acetate and methanol omitted, was prepared under $\mathrm{N}_{2}$ and used for substrate-utilization studies. Anaerobic stocks of filter-sterilized substrates (sodium formate, sodium acetate, trimethylamine, methanol, 2-propanol, and isobutanol) were prepared and added separately at final concentrations of $50 \mathrm{mM}$. Freshly grown cultures of each isolate were inoculated at $10 \%(\mathrm{v} / \mathrm{v})$ and vials were incubated at $38^{\circ} \mathrm{C}$ for 20 days. The basal medium under $\mathrm{H}_{2} / \mathrm{CO}_{2}$ served as the control.

The optimal temperature for growth in the basal medium was determined at optimal $\mathrm{pH}$. Vials inoculated with $10 \%(\mathrm{v} / \mathrm{v})$ culture were incubated at temperatures ranging from $20^{\circ} \mathrm{C}$ to $50^{\circ} \mathrm{C}$. The vials were pressurized every other day with $\mathrm{H}_{2} / \mathrm{CO}_{2}$ to ensure an adequate supply of substrate.

The optimal $\mathrm{pH}$ for growth in the basal medium was determined at the optimum temperature, with $\mathrm{pH}$ values ranging from 4.0 to 9.0. Values above $\mathrm{pH} 4.0$ were produced by adding sterile $\mathrm{Na}_{2} \mathrm{CO}_{3}$ to media at $\mathrm{pH} 4.0$ until the required value was reached. $\mathrm{pH} 4.0$ medium was prepared by omitting $\mathrm{NaHCO}_{3}$ from the basal medium and cooling it under a $\mathrm{CO}_{2}$ headspace.

The sensitivity of strains KOR-3, $-4,-5$, and -6 to ampicillin, penicillin $\mathrm{G}$, spectromycin, kanamycin, tetracycline, and chloramphenicol (all at a concentration of $100 \mu \mathrm{g} / \mathrm{mL}$ ) was tested. Aliquots $(5 \mathrm{~mL})$ of the cultures were inoculated into fresh media containing one of the six antibiotics. Strains KOR-3, -4, -5, and -6 were incubated for 1 week at $38^{\circ} \mathrm{C}$. The effect of antibiotics was determined by comparing the growth of cultures containing these antibiotics to that of the control.

The salinity range of the isolates was tested at $\mathrm{NaCl}$ concentrations ranging from $0.5 \%$ to $3.0 \% \mathrm{NaCl}$, with $0.5 \%$ intervals. Media with various concentrations of $\mathrm{NaCl}$ were prepared by adding a sterile anoxic stock solution of $58.44 \mathrm{~g} / \mathrm{L} \mathrm{NaCl}$ to the media.

\section{Microscopy}

An Olympus BX41 phase-contrast microscope (Olympus, Tokyo, Japan) was routinely used to observe cells. A standard Gramstain kit (BBL Microbiology Systems, Becton Dickinson, Bergen County, NJ, USA) was used to determine the Gram-staining character. Motility was determined by the hanging-drop method, using a glass cavity slide.

\section{DNA extraction}

Culture samples of strains KOR-3, -4, -5, and -6 grown in the basal media were used for DNA isolation (FastDNA SPIN kit for soil, MP Biomedicals, Irvine, CA, USA) following the manufacturer's instructions. DNA integrity was checked on $1 \%$ agarose gels and DNA concentration was determined using a Nanodrop (ND 2000, Thermo Fisher Scientific, Waltham, MA, USA).

\section{Polymerase chain reaction amplication of $16 \mathrm{~S}$ rRNA genes} 16S rRNA gene amplicons ( 1,350 bp) were obtained using the following primer pair: Ar109f (5'- ACKGCTCAGTAACACGT-3') [12] and Ar1383r (5'-CGGTGTGTGCAAGGAGCA-3') [13]. Reaction mixtures contained the following components in a final volume of $20 \mu \mathrm{L}$ within a $200-\mu \mathrm{L}$ PCR tube: $2 \mu \mathrm{L}$ PCR buffer (Takara, Tokyo, Japan), $2 \mu \mathrm{L}$ dNTP mix ( $35 \mathrm{mM}), 0.5 \mu \mathrm{L}$ each primer (10 pmol/ $\mu \mathrm{L}$ ), $0.1 \mu \mathrm{L}$ Taq DNA polymerase (Takara, Japan), 1.0 $\mu \mathrm{L}$ template DNA sample (100 ng), and $13.9 \mu \mathrm{L}$ molecular grade water (Severn Biotech Ltd, Kidderminster, Worcester, UK). The PCR was started by immediately placing the reaction tubes into the preheated $\left(94^{\circ} \mathrm{C}\right)$ thermal cycler (PCR Thermal Cycler Dice, Takara, Japan). The thermal program was as follows: an initial denaturation step $\left(94^{\circ} \mathrm{C}, 4 \mathrm{~min}\right)$ followed by 30 cycles of denaturation $\left(94^{\circ} \mathrm{C}, 30 \mathrm{~s}\right)$, annealing $\left(55^{\circ} \mathrm{C}, 30 \mathrm{~s}\right)$, and extension $\left(72^{\circ} \mathrm{C}\right.$, $90 \mathrm{~s})$. After a final extension step $\left(72^{\circ} \mathrm{C}, 6 \mathrm{~min}\right)$, samples were kept at $4^{\circ} \mathrm{C}$ until further analysis. Each PCR run included a positive control, DNA extracted from pure cultures, and a negative PCR control where molecular grade water was substituted for the DNA template. The DNA product was analyzed using gel electrophoresis $(1.2 \% \mathrm{w} / \mathrm{v}$ agarose gel stained and run at $100 \mathrm{~V}$ for $30 \mathrm{~min}$ in $1 \times$ Tris-acetate-ethylene-diamine-tetraacetic acid [EDTA] buffer with $5 \mu \mathrm{L}$ aliquots of each DNA product). The tris-acetate-EDTA (TAE) buffer was composed of $40 \mathrm{mM}$ Tris base, $20 \mathrm{mM}$ acetic acid, and 0.5 M EDTA (pH 8.0). The gel was run with $2.5 \mu \mathrm{L}$ of Ladder I DNA quantification marker (TNT research, Seoul, Korea). The gel was imaged using the Bio Imaging System (Daihan, Seoul, Korea) and photographs were taken using WiseCapture II software (Daihan, Korea).

\section{Polymerase chain reaction amplification of $m c r A$ genes} The $m c r A$ genes fragments were amplified using the primer combinations MLf (5'-GGTGGTGTMGGATTC ACACARTAYGC WACAGC-3') and MLr (5'-TTCATTGCRTAGTTWGGRTAG TT-3'), yielding 490 bp amplicons [14]; ME1 (5'-GCMATGCA RATHGGWATGTC-3') and ME2 (5'-TCATKGCRTA GTTDGG 
RTAGT-3'), yielding 740 bp amplicons [15]; and MR1 (5'-GACC TCCACTWCGT VAACAACGC-3') and ME2, yielding amplicons of $\sim 1,100$ bp [16]. Denaturation, annealing, and extension were carried out at $96^{\circ} \mathrm{C}(15 \mathrm{~s}), 55^{\circ} \mathrm{C}(30 \mathrm{~s})$, and $72^{\circ} \mathrm{C}(90 \mathrm{~s})$, respectively, with MLf/MLr primers, and $94^{\circ} \mathrm{C}(40 \mathrm{~s}), 50^{\circ} \mathrm{C} \mathrm{(45} \mathrm{s),} \mathrm{and}$ $72^{\circ} \mathrm{C}$ (90 s), respectively, with ME1/ME2 and MR1/ME2 primers.

\section{Phylogenetic and sequencing analysis}

PCR products were purified with the AccuPrep PCR purification kit (Bioneer, Daejeon, Korea). Sequencing of PCR products was performed using the BigDye terminator cycle sequencing kit on ABI 3730XL capillary DNA Sequencer (Applied Biosystems, Thermo Fisher Scientific Inc., Carlsbad, CA, USA). 16S rRNA and $m c r A$ gene sequences from the isolated strains were compared to that of similar sequences obtained from GenBank using the BLAST program. Phylogenetic analysis was conducted using MEGA 4.0 [17]. We examined nine additional 16S rRNA sequences (M. mazei [NR041956], M. acetivorans [NR044724], Methanoculleus receptaculi [NR043961], Methanomicrobium mobile [NR 044726], Methanosphaera stadtmanae [M59139], Methanobacterium alcaliphilum [NR028228], Methanobacterium subterraneum [NR028247], Methanobacterium formicicum [JQ973735], and Methanobacterium formicicum [AF169245]). Phylogeny was further confirmed by $m c r A$ gene and $m c r A$ protein sequences $(M$. mazei [AB703645], M. barkeri [Y00158], M. lacustris [AY260439], Methanopyrus kandleri [U57340], Methanobacterium kanagiense [AB551869], Methanobacterium formicicum [EF465103], and Methanobacterium formicicum [JX141395]).

\section{Nucleotide sequence accession number}

The 16S rRNA and $m c r A$ gene sequences of strains KOR-3, $-4,-5$, and -6 determined in this study were deposited in the GeneBank database under No JX560177-JX560180, KC292221-KC292223, and $\mathrm{KC} 150017$.

\section{RESULTS AND DISCUSSION}

\section{Characterization of isolated methanogens}

New methanogens were isolated from an anaerobic digester that uses pig slurry. Pure cultures were obtained after repeated transfer in the presence of antibiotic mixtures for at least half a year and up to two years. On solid media, colonies were irregularly shaped, white (KOR-3 and -4) or yellow (KOR-5 and -6), and about $0.8 \mathrm{~mm}$ in diameter after incubation for two weeks. The cultures were comprised of small and irregular cocci (diameter, $0.5 \mu \mathrm{m}$ to $1.5 \mu \mathrm{m}$ ) occurring singly and in pairs, which is similar to previous reports for M. mazei (Table 1) [4]. The cell wall was Gram-negative. Although a few cells of strains KOR-3, -4, -5, and -6 demonstrated sarcina, the shape of most cells were that of irregular cocci, which is similar to reports by Cairó et al [5] and Lai et al [18]. M. mazei could be distinguished from other Methanosarcina species by their ability to grow as single cells
Table 1. Comparative characteristics of strains KOR-3, 4, -5, and -6 isolated from an anaerobic digester that uses pig slurry

\begin{tabular}{|c|c|c|c|c|}
\hline Characteristics & KOR-3 & KOR-4 & KOR-5 & KOR-6 \\
\hline Gram staining & - & - & - & - \\
\hline Cell morphology & Coccoid & Coccoid & Coccoid & Coccoid \\
\hline Cell width $(\mu \mathrm{m})$ & $0.5-1.5$ & $0.5-1.5$ & $0.5-1.5$ & $0.5-1.5$ \\
\hline \multicolumn{5}{|c|}{ Temperature for growth $\left({ }^{\circ} \mathrm{C}\right)$} \\
\hline Range & $20-40$ & $20-40$ & $20-40$ & $20-40$ \\
\hline Optimum & 39 & 39 & 39 & 39 \\
\hline \multicolumn{5}{|l|}{ pH for growth } \\
\hline Range & $4.0-9.0$ & $4.0-9.0$ & $4.0-9.0$ & $4.0-9.0$ \\
\hline Optimum & $6.8-7.2$ & $6.8-7.2$ & $6.8-7.2$ & $6.8-7.2$ \\
\hline \multicolumn{5}{|c|}{$\mathrm{NaCl}$ for growth range (\%) } \\
\hline Range & $0.5-3.0$ & $0.5-3.0$ & $0.5-3.0$ & $0.5-3.0$ \\
\hline Optimum & 1.0 & 0.5 & 1.0 & 1.0 \\
\hline \multicolumn{5}{|l|}{ Substrate utilization } \\
\hline $\mathrm{H}_{2} / \mathrm{CO}_{2}$ & - & - & - & - \\
\hline Formate & - & - & - & - \\
\hline Acetate & + & + & + & + \\
\hline Methanol & - & - & + & + \\
\hline Trimethylamine & - & - & + & + \\
\hline 2-propanol & - & - & - & - \\
\hline |sobutanol & - & - & - & - \\
\hline \multicolumn{5}{|c|}{ Tolerance for antibiotics } \\
\hline Ampicillin & + & + & + & + \\
\hline Penicillin G & + & + & + & + \\
\hline Spectromycin & + & + & + & + \\
\hline Kanamycin & + & + & + & + \\
\hline Tetracycline & + & + & + & + \\
\hline Chloramphenicol & - & - & - & - \\
\hline
\end{tabular}

-, negative; +, positive.

under appropriate condition, and Xun et al [19] found medium that could induce the disaggregation of $M$. mazei S-6. The variable disaggregation of all isolated strains in the study may have been because the culture condition was not appropriate for the disaggregation of the strains. It was reported the enzyme disaggregatase could be released into the medium and play a role in disaggregation [4]. Therefore, culture conditions may influence the release or activity of this enzyme.

KOR-3 and KOR-4 strains were able to use acetate but were unable to use formate, methanol, 2-propanol, isobutanol, or $\mathrm{H}_{2} /$ $\mathrm{CO}_{2}$ as a substrate for growth and methane production (Table 1). KOR-5 and KOR-6 strains consumed acetate, methanol, and trimethylamine to produce methane but did not use $\mathrm{H}_{2} / \mathrm{CO}_{2}$, formate, 2-propanol, or isobutanol as a growth substrate (Table 1). Acetate is known to be a precursor for more than $70 \%$ of $\mathrm{CH}_{4}$ formation in most anaerobiosis [20]. Methanosarcina sp. and Methanosaeta sp. were identified as two types of methanogens capable of metabolizing acetate [21]. It was reported that $M$. barkeri, M. mazei, and M. vacuolata could be distinguished from other methanogens by their ability to produce methane from trimethylamine, methanol, and acetate [22]. The most acetotrophic Methanosarcina species described, including M. acetivorans [23] and Methanosarcina thermophile [24] are unable to oxidize 
$\mathrm{H}_{2}$ or reduce $\mathrm{CO}_{2}$ to methane. From both our data and that of others, strains of M. mazei, such as strains O1M9704, GFJ07, TMA, S-6T, JC3, JC2, LYC, N2M9705, and KOR-3, -4, -5, and -6 , could not use formate as a substrate. Based on morphology and substrate utilization of the four isolated strains in this experiment, this may be a basic characteristic of M. mazei.

The growths of strains isolated in this study were observed at a temperature range of $20^{\circ} \mathrm{C}$ to $40^{\circ} \mathrm{C}$, with the fastest growth occurring at $39^{\circ} \mathrm{C}$ (Table 1 ). The $\mathrm{pH}$ range used for growth was 4.0 to 9.0, and the optimum $\mathrm{pH}$ for growth was 6.8 to 7.2 for the strains. The temperature and $\mathrm{pH}$ values of strains $\mathrm{KOR}-3,-4,-5$, and -6 were mostly consistent with that of other M. mazei strains. Oren [22] reviewed that the optimum temperature and optimum $\mathrm{pH}$ of M. mazei strains ranged from $30^{\circ} \mathrm{C}$ to $40^{\circ} \mathrm{C}$ and 6.8 to 7.2 , respectively. However, some strains related to $M$. mazei, M. lacustris, or Methanomethylovorans hollandica can be found at lower temperature $\left(5^{\circ} \mathrm{C}\right.$ to $\left.6^{\circ} \mathrm{C}\right)$ and have been isolated from tundra wetland soil, a Russian pond polluted with paper-mill waste, anoxic sediments from a Swiss lake, and from an anaerobic digester for cattle manure operated at $6^{\circ} \mathrm{C}[16]$. Although the best known strains of $M$. mazei grow fast at neutral $\mathrm{pH}$, some can optimally grow at $\mathrm{pH} 8.5$ and tolerate alkaline conditions up to $\mathrm{pH} 9.5$ in places such as cow dung [25]. The strains isolated in this study can also tolerate $\mathrm{pH}$ value up to 9.0.

All of the isolated strains used in our experiments could grow well in salinity up to $3.0 \%(\mathrm{w} / \mathrm{v})$. The optimum $\mathrm{NaCl}$ concentration for KOR-3, -5 , and -6 and KOR-4 was $1.0 \%$ and $0.5 \%$ (w/v), respectively (Table 1). Certain species of Methanosarcina are halophilic or halotolerant in nature, such as Methanosarcina thermophila, which can grow in up to $7.0 \%(\mathrm{w} / \mathrm{v}) \mathrm{NaCl}$, with optimum growth occurring at $3.5 \%(\mathrm{w} / \mathrm{v}) \mathrm{NaCl}[21]$ and $M$. barkeri A-12 and A-13, which can grow in up to $3 \% \mathrm{NaCl}$, with optimum growth occurring at $0.06 \% \mathrm{NaCl}$ [26]. Thakker and Ranade [27] also described isolate $\mathrm{LN} 1$, which grew in $3 \% \mathrm{NaCl}$. It is known that the halophilic or halotolerant characteristics of Methanosarcina are due to osmotic adaptation using glycine betaine, $\alpha$ glutamate, $\mathrm{N}^{\varepsilon}$-acetyl- $\beta$-lysine, and $\mathrm{K}^{+}$as compatible solutes [28] Compared to these species, the optimal growth for strain KOR-4 was $0.5 \%(\mathrm{w} / \mathrm{v})$ salt, which is lower than that of the other isolated strains used in this study-even though KOR-4 can also grow with up to $3 \% \mathrm{NaCl}$.

All of the strains tolerated ampicillin, penicillin G, kanamycin, spectromycin, and tetracycline. In contrast, chloramphenicol inhibited cell growth. Clarens et al [29] reported that M. mazei, such as strains JC3, S-6, and MC3, was completely inhibited by chloramphenicol. Hilpert et al [30] found that archaea were insensitive to many antibiotics that act against eubacteria and eukaryotes, such as those inhibiting the synthesis or cross-linkage of the peptide subunit of murein or those that inhibit the synthesis of RNA. Thus, the strains KOR-3, $-4,-5$, and -6 are also insensitive to antibiotics used in our experiment, with the exception of chloramphenicol. As Hilpert et al [30] mentioned in their report, the protein inhibitor chloramphenicol, together with lasalocid and monensin, interferes with the cell membrane function

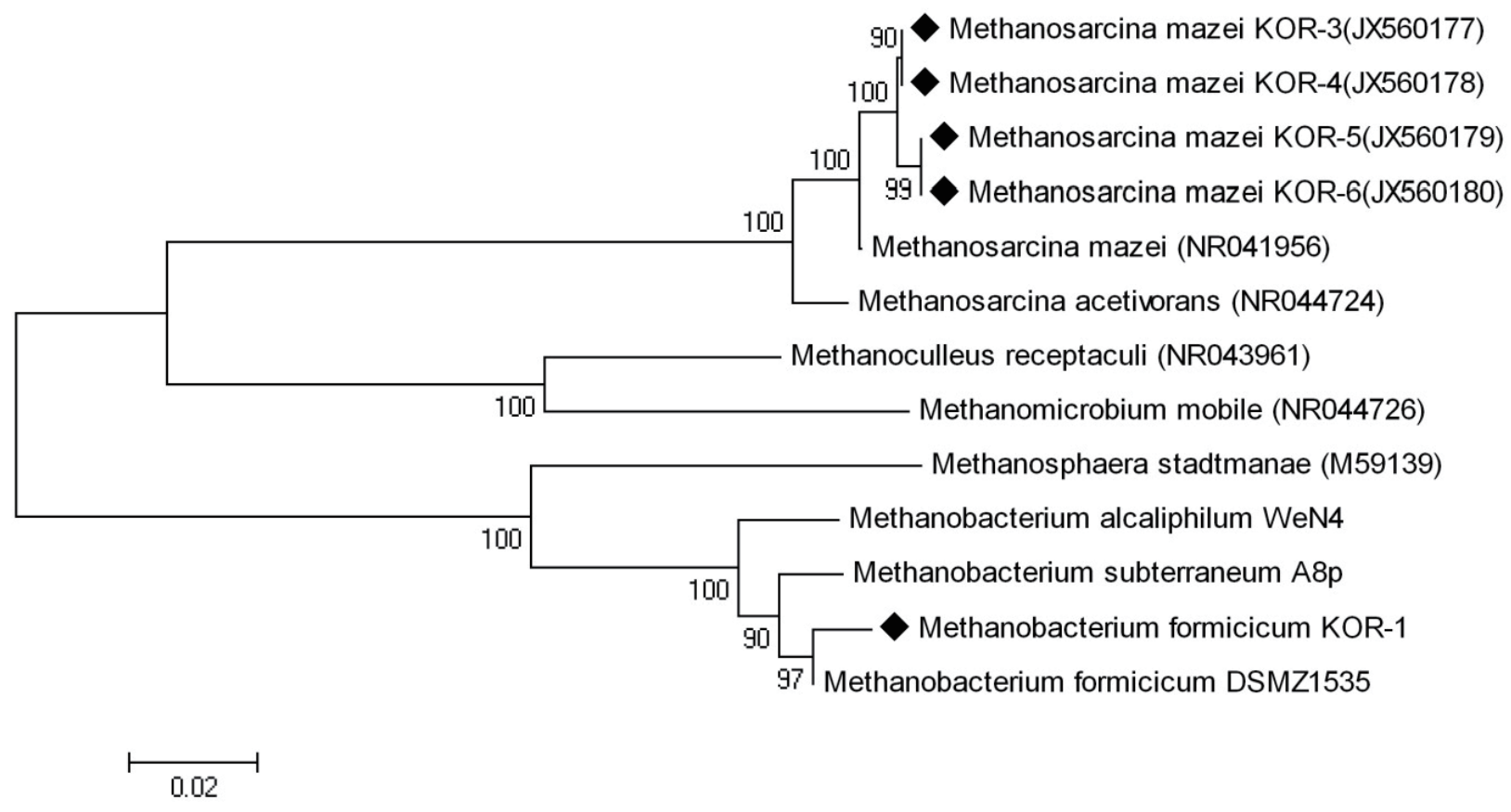

Figure 1. Phylogenetic dendrogram of 165 rRNA gene sequences showing the position of Methanosarcina mazei strain KOR-3, 4, -5 , and - 6 relative to other species of the genus Methanosarcina as well as selected reference sequences of methanogens. Methanomicrobium mobile and Methanoculleus receptaculi were used as outgroup references. The evolutionary distances were computed using the maximum composite likelihood method [17]. Bootstrap values are shown at nodes (percentages of 500 replicates). GenBank accession numbers are indicated. $\mathrm{A}$ bar represents 0.02 substitutions per nucleotide position. 
of methanogens. However, it remains to be shown whether this insensitivity to chloramphenicol is due to the impermeability of the cytoplasmic membrane or to inactivation of the antibiotic by the cell, rather than the absence of a particular target for the antibiotic [30].

\section{Molecular characterization}

PCR of 16S rRNA yielded an amplicon size of 1,350 bp. mcrA Gene-based amplification was also used for identification purposes and it resulted in a product size of $1,100 \mathrm{bp}$. A large fragment of the $16 \mathrm{~S}$ rRNA gene $(\sim 1,350 \mathrm{bp})$ was obtained from isolates and sequenced. Comparative $16 \mathrm{~S}$ rRNA gene sequence analysis showed that the strains were affiliated with the order Methanosarcinales. The closest relatives of strains KOR-3, -4, and -6 were M. mazei (99\%, sequence similarity) and M. acetivorans (94\%) (Figure 1). The $16 \mathrm{~S}$ rRNA sequence similarity of KOR-5 was $98 \%$ compared with $M$. mazei showing a small difference between KOR-5 and KOR-6 which they have no difference in physiological characteristics in Table 1. MCR, the terminal enzyme complex in the methane generation pathway that catalyzes the reduction of a methyl group bound to coenzyme $M$, is associated with the release of methane and is thought to be unique to, and ubiquitous in, methanogens [31]; therefore, it makes an ideal tool for their specific detection. Thus, mcrA gene, which encodes one peptide of the MCR complex, is a suitable candidate for the development of PCR-based detection of methanogens [14] and use of this functional gene serves to complement analysis of the 16S rRNA gene to provide an improved assessment of methanogen diversity [32]. Application of the $m c r A$ gene for analysis of Methanosarcinales has been previously performed [33]. For PCR amplification of the $m c r A$ gene, we used primers MLr/MLf, ME1/ ME2 [15], and MR1/ME2 [16] to obtain nearly the full-length $m c r A$ gene. The $m c r A$ gene sequence also indicated that the strains were a member of the order Methanosarcinales. The closest relatives based on mcrA gene sequences were $M$. mazei (99\%), $M$. acetivorans (94\%), and M. barkeri (92\%) (Figure 2). Additionally, we rendered the sequence part of the $m c r A$ gene $(1,100 \mathrm{bp})$ to amino acids (AA) and then assembled a molecular phylogenetic tree based on the MCR II alpha subunit sequences of the mcrA gene. The AA sequences of the $m c r A$ gene-based tree further demonstrated that the strains were members of the order Methanosarcinales (Figure 3). No major differences were found between the DNA and AA sequences or between the different algorithms that were used (Figures 2, 3). The phylogenetic tree based on the $16 \mathrm{~S}$ rRNA gene (Figure 1) sequence showed two major clusters. Cluster 1 and 2 in the tree were completely different from each other. Cluster 1 comprised two sub-clusters and KOR-3, -4, -5, and -6 in sub-cluster 1 showed $100 \%$ similarity with the $m c r A$ gene of $M$. mazei (Figure 2). The protein sequences (Figure 3) showed two major clusters: cluster 1 comprised two sub-clusters with KOR-3, -4, -5, and -6 in sub-cluster 1, showing 100\% similarity to that of M. mazei. All three approaches showed similar phylogenetic results and, thus, are in accordance with [14] who stated that the $m c r A$ gene sequence can be used an alternative to $16 \mathrm{~S}$ rRNA-based sequences methods, demonstrating far greater diversity than that of $16 \mathrm{~S}$ rRNA gene sequences in the methanogen population.

On the basis of morphology, physiological characteristics, and phylogenetic analyses described above, the strains were identified as new strains of M. mazei, namely, KOR-3, -4, -5, and -6.

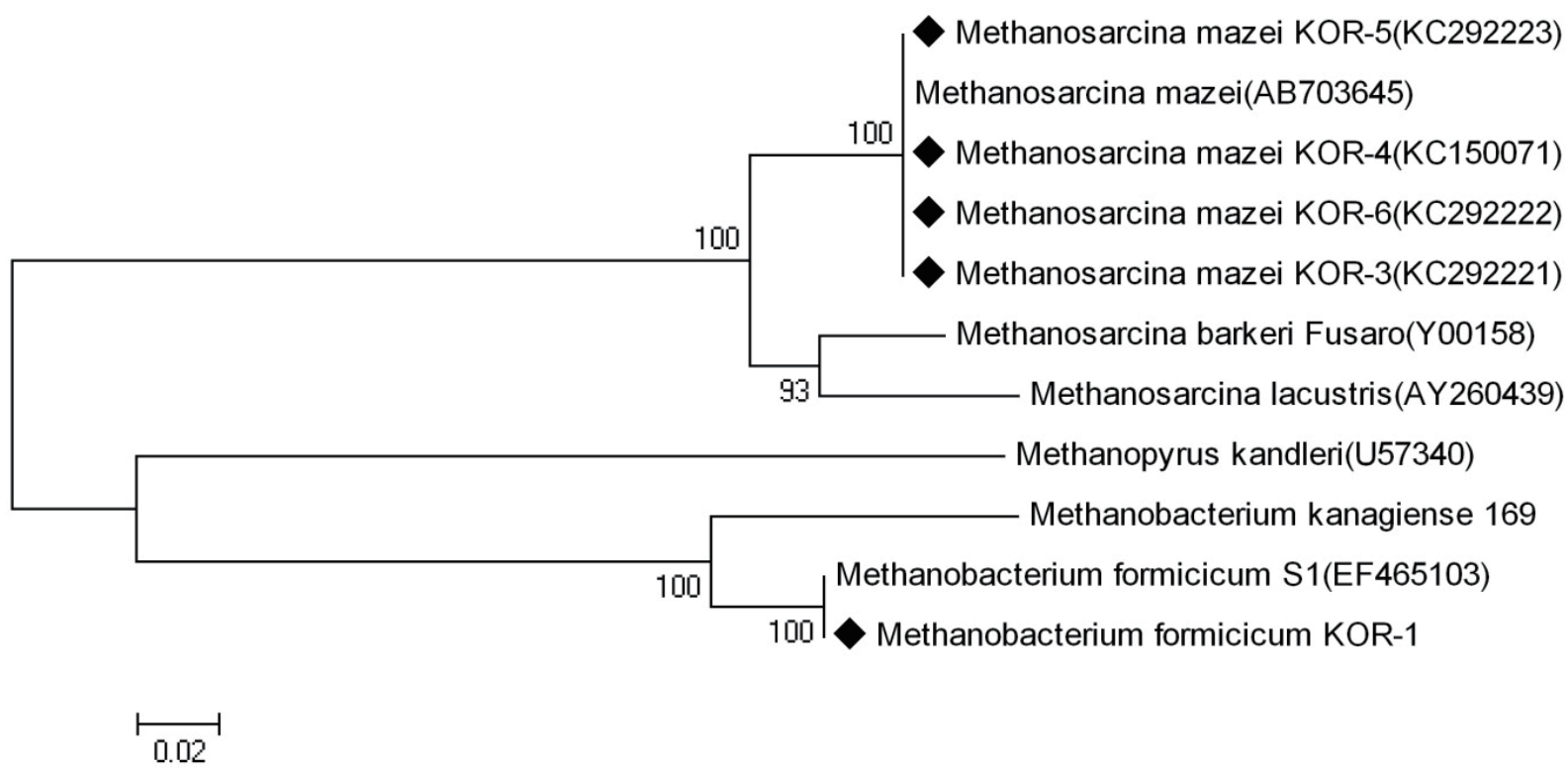

Figure 2. Phylogenetic tree of deduced mcrA gene sequences indicating the relationship of Methanosarcina mazei strain KOR-3, 4, -5 , and -6 to members of the genus Methanosarcina and other methanogenic archaea. Methanopyrus kandleri and Methanobacterium formicicum were used as outgroup references. GenBank accession numbers are indicated. Bootstrap values are shown at nodes (percentages of 500 replicates). A bar represents 0.02 substitutions per nucleotide position. 


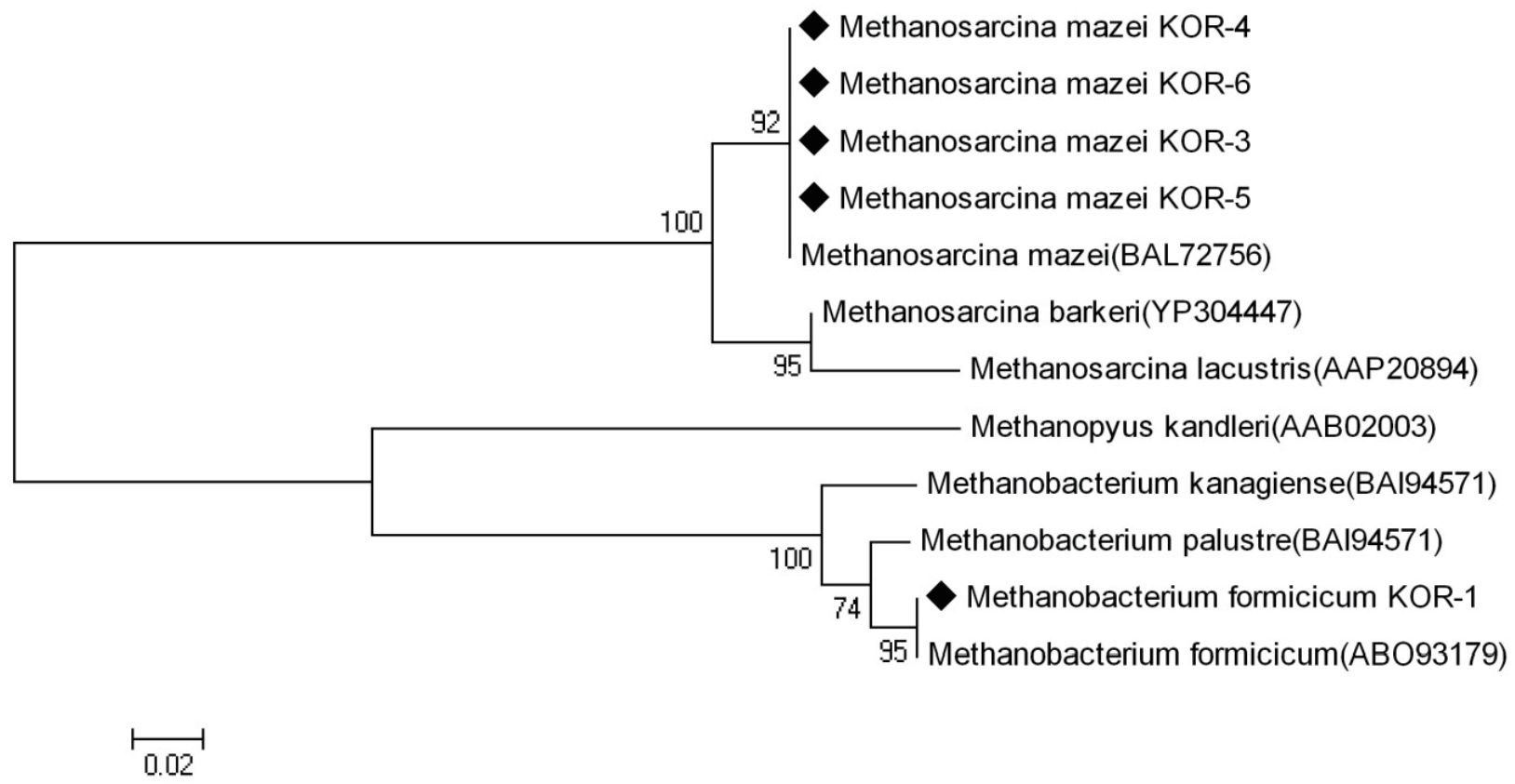

Figure 3. Phylogenetic tree of deduced $m c r A$ amino acid sequences showing the relationship of Methanosarcina mazei strain KOR-3, 4, -5 , and -6 to related methanogenic archaea. The tree was constructed based on distance matrices (383 amino acid positions; Poisson correction) by the neighbor-joining method. The sequence of Methanopyrus kandleri and Methanobacterium formicicum were used as the outgroup reference. A bar represents 0.02 substitutions per nucleotide position.

\section{CONFLICT OF INTEREST}

We certify that there is no conflict of interest with any financial organization regarding the material discussed in the manuscript.

\section{ACKNOWLEDGMENTS}

This work was supported by the Korean Institute of Planning and Evaluation for Technology in Food, Agriculture, Forestry and Fisheries (IPET) through the High Value-added Food Technology Development Program, funded by the Ministry for Food, Agriculture, Forestry, and Fisheries (MAFRA) (314075-3).

\section{REFERENCES}

1. Dabert P, Vedrenne F, Brard C, Béline F. Microbiological aspects of methane production during pig manure storage. In: 13th Ramiran international conference, potential for simple technology solutions in organic manure management; 2008 June 11; Albena, France: 2008. p. 96-9.

2. Martinez J, Guiziou F, Peu P, Gueutier V. Influence of treatment techniques for pig slurry on methane emissions during subsequent storage. Biosyst Eng 2003;85:347-54.

3. Garcia JL, Patel BKC, Ollivier B. Taxonomic phylogenetic and ecological diversity of methanogenic archaea. Anaerobe 2000;6:205-26.

4. Li Y, Lan K, Rong Y, et al. Isolation and characterization of a new Methanosarcina mazei strain GFJ07 from a mountain forest pond. Malaysian J Microbiol 2012;8:6-10.
5. Cairó JJ, Clarens M, Touzel JP, Bardulet M, París JM. Methanosarcina mazei JC2, a new methanogenic strain isolated from lake sediments, that does not use $\mathrm{H}_{2} / \mathrm{CO}_{2}$. Microbiologia (Madrid, Spain) 1992;8:2131 .

6. Chouari R, Le Paslier D, Daegelen P, et al. Novel predominant archaeal and bacterial groups revealed by molecular analysis of an anaerobic sludge digester. Environ Microbiol 2005;7:1104-15.

7. Kim YS, Yoon YM, Kim CH, Giersdorf J. Status of biogas technologies and policies in South Korea. Renew Sust Energ Rev 2012;16:3430-8.

8. Battumur U, Yoon YM, Kim CH. Isolation and characterization of a new Methanobacterium formicicum KOR-1 from an anaerobic digester using pig slurry. Asian-Austral J Anim Sci 2016;29:586-93.

9. Hungate RE. The anaerobic mesophilic cellulolytic bacteria. Bacteriol Rev 1950;14:1-49.

10. Balch WE, Fox GE, Magrum LJ, Woese CR, Wolfe RS. Methanogens: reevaluation of a unique biological group. Microbiol Rev 1979;43:26096.

11. Sowers KR, Schreier HJ. Media for methanogens. In: Sowers KR, Schreier HJ, editors. Archaea - a laboratory manual methanogens. New York: Cold Spring Harbor Laboratory Press; 1995. p. 459-89.

12. Großkopf R, Janssen PH, Liesack W. Diversity and structure of the methanogenic community in anoxic rice paddy soil microcosms as examined by cultivation and direct $16 \mathrm{~S}$ rRNA gene sequence retrieval. Appl Environ Microbiol 1998;64:960-9.

13. Shlimon AG, Friedrich MW, Niemann H, Ramsing NB, Finster K. Methanobacterium aarhusense sp. nov., a novel methanogen isolated from a marine sediment (Aarhus Bay, Denmark). Int J Syst Evol Micrbiol 2004;54:759-63. 
14. Luton PE, Wayne JM, Sharp RJ, Riley PW. The mcrA gene as an alternative to $16 \mathrm{~S}$ rRNA in the phylogenetic analysis of methanogen populations in landfill. Microbiol 2002;148:3521-30.

15. Hales BA, Edwards C, Ritchie DA, et al. Isolation and identification of methanogen-specific DNA from blanket bog feat by PCR amplification and sequence analysis. Appl Environ Microbiol 1996;62:668-75.

16. Simankova MV, Kotsyurbenko OR, Lueders T, et al. Isolation and characterization of new strains of methanogens from cold terrestrial habitats. Syst Appl Microbiol 2003;26:312-8.

17. Tamura K, Dudley J, Nei M, Kumar S. MEGA4: molecular evolutionary genetics analysis (MEGA) software version 4.0. Mol Biol Evol 2007; 24:1596-9.

18. Lai MC, Shu CM, Chen SC, et al. Methanosarcina mazei strain O1M9704, methanogen with novel tubule isolated from estuarine environment. Curr Microbiol 2000;41:15-20.

19. Xun LY, Mah RA, Boone DR. Isolation and characterization of disaggregatase from Methanosarcina mazei LYC. Appl Environ Microbiol 1990;56:3693-8.

20. Rocheleau S, Greer CW, Lawrence JR, et al. Differentiation of Methanosaeta concilii and Methanosarcina barkeri in anaerobic mesophilic granular sludge by fluorescent in situ hybridization and confocal scanning laser microscopy. Appl Environ Microbiol 1999;65:2222-9.

21. Ferry JG. Methanogenesis: ecology, physiology, biochemistry and genetics. New York, NY: Chapman \& Hall; 1993.

22. Oren A. The family Methanosarcinaceae. In: Rosenberg E, DeLong EF, Lory S, Stackebrandt E, Thompson F, editors. The Prokaryotes: other major lineages of bacteria and the archaea. Berlin, Germany: Springer; 2014. p. 259-81.

23. Sowers KR, Baron SF, Ferry JG. Methanosarcina acetivorans sp. nov., an acetotrophic methane producing bacterium isolated from marine sediments. Appl Environ Microbiol 1984;47:971-8.
24. Zinder SH, Sowers KR, Ferry JG. Methanosarcina thermophila sp. nov., a thermophilic, acetotrophic, methane producing bacterium. Int J Syst Bacteriol 1985;35:522-3.

25. Qian D, Ma L, Yuan Y, et al. Isolation, identification and phylogenetic analysis of an alkalophilic Methanosarcina. Chinese J Appl Environ Biol 2012;2012:262-6.

26. Kadam PC, Godbole SH, Ranade DR. Isolation of methanogens from Arabian sea sediments and their salt tolerance. FEMS Microbiol Ecol 1989;62:343-7.

27. Thakker CD, Ranade DR. An alkalophilic Methanosarcina isolated from Lonar crater. Curr Sci 2002;82:455-8.

28. Sowers KR, Gunsalus RP. Halotolerance in Methanosarcina spp.: role of $\mathrm{N}^{\varepsilon}$-acetyl- $\beta$-lysine, $\alpha$-glutamate, glycine betaine, and $\mathrm{K}^{+}$as compatible solutes for osmotic adaptation. Appl Environ Microbiol 1995;61: 4382-8.

29. Clarens M, Cairó JJ, París JM, Macario AJL, de Macario EC. Characterization and forms of JC3, a new Methanosarcina isolate: comparison with Methanosarcina mazei strains S- $6^{\mathrm{T}}, \mathrm{MC} 3$, and LYC. Curr Microbiol 1993;26:167-74.

30. Hilpert R, Winter J, Hammes W, Kandler O. The sensitivity of archaebacteria to antibiotics. Zbl Bakt Mik Hyg I C 1981;2:11-20.

31. Thauer RK. Biochemistry of methanogenesis: a tribute to Marjory Stephenson. Microbiol 1998;144:2377-406.

32. Wilkins D, Lu XY, Shen Z, Chen J, Lee PKH. Pyrosequencing of $m c r A$ and archaeal $16 \mathrm{~S}$ rRNA genes reveals diversity and substrate preferences of methanogen communities in anaerobic digesters. Appl Environ Microbiol 2015;81:604-13.

33. Springer E, Sachs MS, Woese CR, Boone DR. Partial gene sequences for the a subunit of methyl-coenzyme $\mathrm{M}$ reductase ( $\mathrm{mcr}$ ) as a phylogenetic tool for the family Methanosarcinaceae. Int J Syst Bacteriol 1995;45:554-9. 